\title{
Trade Unions and Democratization in Tanzania: End of an Era?
}

\author{
Edwin Babeiya \\ Assistant Lecturer \\ Department of Political Science and Public Administration \\ Dar es Salaam University College of Education (DUCE) \\ University of Dar es Salaam \\ P.O. Box 2329Dar es Salaam, Tanzania \\ E-mail: babeiyae@duce.ac.tz
}

\begin{abstract}
Trade unions have protecting workers' economic rights as their main responsibility. They have, inter alia, to make sure that workers are paid reasonably in a workers-friendly working environment. It is however not canonical that trade unions should only stick to this role especially under a circumstance where public policies are silent about workers interests. In this context, a political role is inescapable as these unions have to go beyond economism and struggle to democratize the state. This paper therefore looks at whether the reintroduction of liberal politics has improved trade unions' ability to influence the state by making it more concerned about workers rights. It is however the view of this paper that the reintroduction of liberal politics in Tanzania has not improved trade unions' ability to democratize the state for they are still apolitical as they were before liberalization.
\end{abstract}

Keywords: Democratization, Politics, Trade unions, Quiescence, Leadership

\section{Introduction}

Trade unions in Tanzania have a long history that can be traced far back since the colonial era. During the colonial period these unions were formed for the purpose of promoting and protecting workers' rights against the colonial state. Notwithstanding their primary objective of promoting the economic interests of their members, they had also a vital role during the struggle for independence. In the course of fighting for independence, these unions joined hands with Tanzania African National Union (TANU) in exerting political pressure to the colonial administration. However, with the country's attainment of independence in 1961 the relationship between trade unions and the ruling party changed significantly suggesting that the two had a marriage of convenience. As the independent government ventured into a myriad of socio-economic policies, political pressure from any social or political organization was taken by the government as inimical to national stability and development. This stance was affirmed by the declaration in 1965 that Tanzania was to be a one party state. As a result, trade unions and other civil society organizations were put under the whims of the ruling party up to the time the country reintroduced liberal politics in early 1990s.

In 1980s Tanzania's prospects for economic development were put at stake following a serious economic crisis (Moshi 1993). It was from the effects of this crisis that the country was forced to embark on socio-economic reforms (Baregu 1993), (Gibbon 1995). Socio economic and political reforms were part of Structural Adjustment Programmes engineered by IMF and the World Bank (Havnevick 1993:288). Political liberalization was however preceded by economic reforms and thus its implementation began with the reintroduction of multiparty politics in Tanzania in 1992 (Bagenda 1994). Multiparty politics marked the end of single party rule and the opening up of the political sphere. However, in spite of the reintroduction of multiparty politics, trade unions were still not legally recognized as autonomous organizations and they could as a result not have a recognizable political role until 1998 when the Trade Unions Act. No.10 was passed by the parliament.

With the reintroduction of plural politics accompanied by new trade unions laws, it was expected that trade unions would enter into a new era of effective participation in democratization processes in Tanzania. Democratization in this paper is conceived of from a liberal perspective to include trade unions' participation in political activities such as policy processes and influencing elections and political actors such as political parties and the government. In this paper, the term democratization is used interchangeably with participation in politics.

One of the implications of liberalization to trade unions' activities was that of opening up the environment in which trade unions were to operate. This was mainly because they were set free from party controls. As Mpangala (2006) argues, with the 1992 reintroduction of multiparty system, civil society organizations which were controlled by the state such as trade unions became free. It is however still not clear whether trade unions have benefited from these socio economic and political changes in the country. This is basically due to the fact that these unions do not seem 
to actively get involved in politics in order to ensure that workers' rights are protected. This paper therefore attempts to assess the role of trade unions in democratization processes after the reintroduction of multiparty politics in Tanzania. It is divided into three main parts. The first part provides a theoretical and historical overview of trade unions and democratization, part two explains a source of a puzzle over trade unions limited role in politics whereas part three tries to provide the reasons for the apolitical nature of trade unions in Tanzania.

\section{Trade unions and democratization in Tanzania: a theoretical and historical overview.}

There have been various views on the role of trade unions in politics, particularly on the question of whether trade unions should or should not participate in democratization processes. On the one hand some scholars such as Webb (1894) and Perlman (1928) view a trade union as simply an association of wage earners for the purpose of maintaining or improving the conditions of their employment. These scholars therefore do not see any political role of trade unions. On the other hand, other scholars such as Przeworski (1989) and Schmitter et al (1986) see trade unions as instrumental and leading associations of civil society in democratization. A similar argument in support of the role of trade unions in politics is that due to their central position in the economy, trade unions can damage the economy through work stoppage and have a continuous organizational base and conducive environment (the workplace) where people can organize without police interference (Rakner 1992). There are two theories that are always used to examine the role of trade unions in democratization namely; the pluralist and corporatist theories.

Within the pluralist perspective, trade unions are seen as autonomous groups competing for power and resources for the benefits of their members. The goals of trade unions are mainly said to be economic geared towards improving the economic welfare of its members. (Note 1)

In order to function effectively in the interests of their members, autonomy from the state is considered essential for trade unions (Martin 1989). While the interests of trade unions in pluralist theory are regarded as narrow and mainly economic rather than political, these unions are assigned an important role in the processes of democratization as they temporarily change towards a political orientation in defense of their long term economic interests.

The Corporatist theory, on the other hand, provides that trade unions have their interests tied to the state through institutional agreements on wage and other welfare issues (Panitch 1979). The theory further states that trade unions are not autonomous from the state and that the relationship between the two is characterised by harmony rather than conflict. It is on this basis that Rakner (1992:40-41) holds the view that the democratizing potential of trade unions under corporatist arrangements is questionable.

Within the Tanzanian context, the environment in which trade unions have been operating can be explained using a historical perspective that indicates different periods through which these unions have passed. The history of trade unions in Tanzania can be traced since 1920s when various associations such as The Kilimanjaro Motor Drivers Association (KMDA), The Tanganyika African Government Servants Association and The Union of Shop Assistants were formed (Tordoff 1967). However these unions did not enjoy freedom as they were subjected to the control from the colonial state (Mihyo 1970). For instance, in an attempt to control workers' resistance, the colonial state introduced the Trade Union Ordinance No.23 of 1932 which conferred much power to the registrar of trade unions to control trade unions (Friedland 1969).

In 1955 trade union movement in Tanzania entered into a new phase and this was after the formation of Tanganyika Federation of Labour (TFL). TFL was formed one year after the formation of a mass independence movement called Tanganyika African National Union (TANU). Due to the prevailing circumstances by that time, the two movements found it necessary to work together. Although the cooperation between TANU and TFL played a significant role to the attainment of independence in 1961, the role of TFL after independence became complex. The union came into direct confrontation with the post independence TANU government over various issues such as Africanization and trade unions' autonomy. (Note 2). In order to contain trade unions, the government abolished TFL in 1964 and established the National Union of Tanganyika Workers (NUTA) which was made an affiliate of the ruling party. It therefore had no power to confront the state in trying to defend workers' interests. NUTA was followed by other trade unions such as Jumuiya ya Wafanyakazi Tanzania (JUWATA) in 1977, Organization of Tanzania Trade Unions (OTTU) in 1990 and the Tanzania Federation of Trade Unions (TFTU) in 1995. However all these unions were not autonomous as they were the victims of strict control from the state. Trade unions in Tanzania were legally made autonomous from 1998 when the OTTU Act was repealed by the Trade Unions Act No. 10 of 1998 in which the Trade Union Congress of Tanzania (TUCTA) as a federation was established in 2001 legally replacing OTTU (Bana \& Mukandala 2006).

The above historical account has clearly shown that for many years trade unions were not free to actively participate in politics. It has also been indicated that since the country introduced liberal politics trade unions are free from state control. However, in spite of this freedom, trade unions in Tanzania are still politically inactive. The next section 
of this paper identifies various contexts which, in spite of their existence, the unions continue to be politically dormant.

\section{Trade unions and political involvement in Tanzania: unveiling a puzzle.}

Trade unions' role in democratization processes in Tanzania has been minimal or nonexistent. What remains to be a puzzle is why trade unions are politically inactive despite the existence of various factors that could have acted as a catalyst to their political struggle. These factors include aspects such as the existence of various workers' problems like poor working conditions, low wages/salaries and policies that are unfriendly to workers, an enabling legal framework, trade unions' internal democracy and the role of other civil society organizations in politics as put forward hereunder.

\subsection{The legal framework}

Very politically active trade unions might be a threat to the political system particularly when they attempt to challenge the status quo and are therefore likely to meet stiff resistance from the state. Gershman and Allen (2006:42) argue that in undemocratic political systems, NGOs and related groups are frequently required to refrain from activities defined broadly to be political. In order to make sure that trade unions keep their mouths shut, various laws are always introduced to control these unions. As pointed out earlier, various laws were introduced by the colonial administration and the independent government in order to control trade unions in Tanzania (Note 3). However, since the reintroduction of liberal politics, the control of trade unions through the legal framework has been decreasing. The provisions of the Employment and labour relations Act No.6 of 2004 (which repealed the trade unions Act of 1998) and the NGOs Act of 2002 do not prohibit trade unions from participating in politics and yet trade unions are politically inactive.

\subsection{Trade unions' internal democracy}

For trade unions to exert more pressure to the political system, certain features have to be in place one of which is the existence of internal democracy. Bwana as quoted by Mpangala (2006:4) proposes that in order for civil society organizations to play a significant role in politics, they must be democratic so as to have social and political legitimacy of influencing the political system. Trade unions in Tanzania have been to a great extent characterized by democratic elements such as participation and competition as these are provided for in the unions' constitutions and adhered to by the trade unionists, independent of controls from any political party. For instance, section 6.1.1 of Tanzania Union of Industrial and Commercial Workers (TUICO) constitution and section 47 (1)-(h), (i) and (j) of the Employment and Labour Relations Act provide for democratic unions' democratic structures. Despite the presence of democratic structures within the unions, trade unions remain politically inactive.

\subsection{The role of other civil society organizations}

One of the surprising realities in Tanzania is that unlike trade unions whose role in politics is unclear, NGOs are politically active in spite of being restricted by the NGOs Act of 2002 to participate in politics. Some of the civil society organizations that have been politically active include Legal and Human Rights Centre (LHRC), Hakielimu, and Research and Education for Democracy in Tanzania (REDET. These organizations have been using various strategies to influence the political processes. For instance some civil society organizations have been adopting a human rights perspective to challenge the political system. Other CSOs have escaped state control under a guise of providing civic education to the public. All these examples indicate the activeness of other civil society organizations in Tanzanian politics as compared with trade unions' limited political role.

\subsection{Persistence of various workers' problems}

Various problems such as poor working conditions, low wages/salaries and policies that are unfriendly to workers continue to affect workers in Tanzania. For instance, workers have always been blaming investment policies as they are said to grant more latitude to foreign investors while neglecting workers' welfare. The conflict within Tanzania Railways Limited (TRL) between the workers and the management was said to be built on these premises (Note 4). With the existence of these problems, trade unions were expected to be more politically active especially at policy making stage so as to make sure that such problems are effectively dealt with by the respective authorities, but they instead remain politically weak. It is on this basis that the next section of this paper identifies and discusses various factors that account for this state of affair.

\section{A quest for trade unions' political quiescence in Tanzania}

The above section has unveiled various aspects which, in spite of their presence, trade unions continue to be politically inactive. The premise of this paper is that the main reasons for trade unions' quiescent political role are; a 
missing bond with opposition political parties, conflicts and individualism, unions' leadership failure and ideological and cultural conservatism.

\subsection{A missing bond with opposition political parties}

Having a partnership with opposition political parties can be used as a means through which trade unions can influence political processes. As Gompers (1987) argues, trade unions need to get involved in politics so as to ensure that those who acquire political leadership will be the ones to formulate policies that are employees' friendly. Contrary to this suggestion, trade unions in Tanzania do not seem to use political parties to champion their interests and as a result they appear to have been ignored by political parties. As pointed out earlier, the history of trade unions in Tanzania shows that they were either willingly or unwillingly using political parties to aggregate their interests to the political system. Currently, there is nothing worthwhile to suggest that this dependence is avoidable given the fact that trade unions are unable to independently play this role by themselves. However, neither the opposition parties nor the trade unions seem interested with this partnership. Explaining this phenomenon thus needs one to apply two lenses in which the first one looks at why trade unions are not interested in establishing a link with opposition parties while the second one examines the rationale behind opposition parties' neglect of trade unions.

\subsubsection{Trade unions versus Political Parties}

One of the reasons that explain the failure of trade unions to forge partnership with opposition parties is the continued control of Tanzania's political sphere by the ruling party (CCM), a fact that is explicit especially during elections. It is on this basis, for example, that Makulilo (2007) contends that Tanzania is a defacto one party state. Since the country reintroduced multiparty politics, the ruling party has had a control of the political processes with the opposition political parties having a very frail role in elections. For instance, in the 2005 general elections, CCM's presidential candidate got more than $80 \%$ of the total votes. As a result, competition for votes between the ruling party and opposition political parties especially at the national level has not been evident. Consequently, these parties do not have an influence in Tanzanian politics to the extent that they can attract the attention of trade unions. This has on the other hand been in favour of the ruling party as with weak opposition parties that have no collaboration with trade unions, it has been in some cases ignoring the trade unions. For instance, in his address to Dar es Salaam elders on $3^{\text {rd }}$, May, 2010, the president of the United Republic of Tanzania Mr. Jakaya Kikwete posed various threats to Trade Unions Congress of Tanzania (TUCTA) which had called a nationwide workers' strike on $5^{\text {th }}$, May, 2010 to demand for more wages and other benefits. In that address, he was quoted as saying "I do not lie to workers by promising what the government cannot afford, even if it would mean losing the election. Even if they go on strike indefinitely, we shall not yield to these demands. We are not afraid of the threat that workers would not vote for us". (Note 5). He also insisted that even if workers decided not to vote for him, he could get the votes elsewhere. Although some opposition parties such as Chama Cha Demokrasia na Maendeleo (CHADEMA) and Civic United Front (CUF) have been recently gaining some popularity in Tanzanian politics, as marked by the increase of electoral competition at constituencies' level between the ruling party's candidates and those of opposition parties, they still trail very far behind the ruling party.

A related fact for trade unions' tendency to pay no heed to political parties has been the fragile nature of opposition political parties in Tanzania. In other African countries such as Zambia, Zimbabwe, Senegal and Ghana, opposition political parties have been stable and strong to the extent that some have managed to remove the ruling parties from power. Since the country embarked on multiparty politics, some parties that had a promising debut have failed to sustain their status to the extent that they no longer pose any threat to the ruling party. For instance, in 1995 the National Convention for Construction and Reform (NCCR) -Mageuzi was the most powerful opposition party but that did not last long as it steadily declined leading to the rise of other parties such as Tanzania Labour Party (TLP), Civic United Front (CUF) and CHADEMA. Like NCCR-Mageuzi, TLP is no longer a force to reckon with for it has hit its lowest ebb in Tanzanian politics as expressed by lack of representation in the national assembly and a drastic fall of its nationwide share of votes. For instance, while TLP's share of nationwide presidential votes in the 2000 general elections was $7.80 \%$, that percentage plummeted to $0.75 \%$ in 2005 general elections. CUF is also suffering from similar problems for, despite its wide geographical presence across all regions in Tanzania, it has no single constituency's Member of Parliament from mainland Tanzania (all its members of parliament are from Zanzibar). Opposition political parties have had a shaky history in which up to the moment there is no single party that can confidently claim to be the most powerful in the country. Apart from the fact that CHADEMA and CUF are somehow powerful, they are yet to win the hearts of trade unionists as their alternative choice. This is basically because of the reality that in spite of having 18 registered opposition political parties, there has been no any single party that identifies itself with the country's labour movements. For instance, unlike in Britain where the Labour Party has close links with British labour Movement and the unions, political parties in Tanzania such as TLP have little or no established connection with the labour movement in the country (Mallya, 2006: 3). For quite a long time the leaders of opposition parties have failed to seriously respond to unions' concerns especially during critical 
moments such as strikes. Some of them have tended to blame the trade unions for not supporting the opposition instead of coming with alternative solutions to workers' problems.

The second reason for trade unions' lack of interest with opposition political parties is due to the fact that since 1992 political parties have failed to introduce policies that can promote partnership with civil society organizations (Mpangala, 2006:14). Since the country adopted liberal politics there has been a growing critic to opposition political parties that they have failed to provide alternative policies to those of the ruling party, most of which are said to neglect workers' interests. During election period, opposition parties have been failing to come up with policies that can capture the attention of trade unionists particularly on issues such as taxation, compensation, health insurance and security of employment. As a result, there has been no significant ideological difference between the ruling party and opposition parties. As Bavu (2006:19) argues, this phenomenon has been providing a political environment in which voters do not find an alternative to the incumbent party. The problem of similarities of policy issues in both the ruling party and the opposition parties is a result of sharing ideological views on development and the political culture of respect to the 'father of the nation' Mwalimu Julius Nyerere as each party strives to be associated with the country's first president.(Note 6). It is on this regard that one finds it very difficult to clearly explain the support of trade unions to opposition political parties during the elections. Trade unionists have had no any alliance with opposition political parties and they have been voting basing on other considerations other than mutual cooperation with political parties.

\subsubsection{Political Parties versus trade unions}

On the other hand, opposition political parties' disregard of trade unions seems to be a result of the following factors; first, trade unions have had no clear political stance. It is not clear whether these unions stick to the traditional client model, think of divorcing the nationalist alliance, live in unhappy marriage or are abstaining from politics. (Note 7). Trade unions' operational framework in Tanzania is rambling and unclear to opposition political parties and thus these parties have been skeptical of trade unions especially on whether or not their marriage with the ruling party was really broken. It is however clear that although the marriage between the two might have been broken following the adoption of multipartism, its legacy within the unions is still obvious.

Second, opposition political parties are doubtful about the support from trade unions' members. Since the country adopted plural politics, the majority of trade unions' members have been apathetic to opposition politics. Their lack of interest to politics is mainly a result of two main factors. The first factor is that most of trade unions' members fear to participate in opposition politics as they are scared of losing their employment which is their major means of livelihood. Since 1961 up to mid 1980s the government was almost the only and main employer and the private sector was yet to flourish. Consequently, a majority of trade unions' members are employed in the public sector and they would always wish to keep their employment safe. This problem is exacerbated by the fact that most of the trade unions are headed by individuals who are or were serving as civil servants. These trade unionists therefore suffer from double loyalty for they have to be obedient to their employers/former employers and serve the trade unions at the same time. This thesis is well supported by the way government officials have been responding to trade unions' actions. For instance, in his address to Dar es Salaam elders on $3^{\text {rd }}$, May, 2010 the president of the united republic of Tanzania issued a warning to all civil servants who were planning to take part in the strike by insisting that they were going to be severely punished, while reminding them he was speaking as the chief of the civil service. The second factor is that the private sector is mostly still informal and those who are in the formal sector are not used to opposition politics to the extent that they can actively participate in confronting the state. The private sector is still infant and its trade unionists are unlikely to effectively address current weaknesses facing the trade unions.

Opposition parties' neglect of trade unions is further attributed to lack of a collective match during the transition to plural politics (the impact of mismatching directions). Having both suffered from the controls of the single party rule, it was expected that trade unions and opposition political parties would join hand in championing the democratization agenda. On the contrary, trade unions in Tanzania, unlike in other African countries whose unions had a direct role in multi party politics, did not actively participate in opposition politics. Their weakness was that they became complacent having been set free from single party controls. In some countries such as Congo-Brazzaville, Zambia, Niger and Mali, trade unions declared their independence from the ruling single party and subsequently played an important role in the transition to multiparty democracy (Schillinger, 2005). In Zambia, for instance, trade unions spearheaded an opposition movement, the Movement for Multi Party Democracy (MMD) whose leader- the former secretary general of ZaCTU, Fredrick Chiluba won the 1991 presidential elections. (Note 8). Having not actively participated in the transition to multi party democracy, opposition political parties do not take trade unions as serious actors in democratization. This observation is supported by Marando (a leader from the opposition camp) who argues that the problem with most of trade unions in Tanzania is that they do not want to cooperate with political parties like what is the case in the developed world (Note 9) The Tanzanian experience 
therefore suggests that with the reintroduction of liberal politics, trade unions mainly concentrated on their own survival and they thus completely neglected politics.

\subsection{Conflicts and Individualism}

Limited trade unions participation in democratization processes is also attributed to internal conflicts within the unions. The main sources of these disorders include financial matters and the struggle for identity. Financial conflicts have involved allegations of embezzlement of the unions' money like what took place in TUCTA where its secretary general was suspended over the allegations of financial mismanagement in 2009. The secretary was accused of using the funds of the trade union for personal gains. On the other hand, the struggle for identity has been involving a debate on the ability/inability of the trade unions to effectively represent the interests of all sections/sectors which are part of the union. As a result, dissatisfied members have been resorting to forming new trade unions. For instance, some TUICO members have recently formed a new union, the Finance, Industrial, Banking, Utilities, Commercial and Agro Processing Industries Trade Union (FIBUCA). Also the Researchers and Academicians Workers Union (RAAWU) has witnessed some of its former members defecting to establish the Tanzania Higher Learning Institutions Trade Union (THTU), so is the case with post office staff who recently shifted their membership from Communication and Transport Workers Union (COTWU) to the newly established trade union, the Telecommunication Workers Union of Tanzania (TEWUTA). As a result of these internal conflicts, more time is spent in dealing with issues that add little or no value to the required efforts for promoting and defending workers' rights.

In addition to lack of internal order, trade unions are unable to effectively participate in democratization due to their failure to establish a strong solidarity that could have helped them stand as a strong collective force. It is evident that trade unions in Tanzania for most of the time have tended to pursue individualistic approaches. Each trade union seems only concerned with the affairs directly related to it and as a result there have been no partnership among these unions in addressing various problems that are affecting the workers. There are various views on the lack of trade unions' solidarity in Tanzania. One of those views is that which associates lack of solidarity with the continuing increase in number of trade unions. Currently there are 24 registered trade unions in Tanzania. However, the increase in number of trade unions does not seem to go hand in hand with a recognition that the prevailing circumstance calls for more partnership among these unions in advancing the interests of their members. As regards the lack of solidarity and partnership among trade unions in Tanzania, Meena (1997) argues;

"It is of interest that teachers were alone in this struggle. They did not get support from other workers who were going through more or less similar crises. This can be attributed to the newness of industrial action in this country. Workers have not developed collective bargaining tactics and therefore strikes end up victimizing individuals and particularly those who take leadership roles. While the university academics had more or less grievances, they did not take this opportunity to fellow teachers and collectively bargain for their rights" (Meena 1997:40)

Meena was explaining about the 1993 incident in which teachers in Dar es Salaam called for a strike against the government in demand for improved working conditions and social welfare as well as higher pay. A similar case that indicates lack of solidarity among trade unions in Tanzania is that of Tanzania Railways Limited (TRL). Since 2008 TRL workers were raising various claims against the new management but they did not get support from other trade unions. Having a union that brings all trade unions together was expected to be a center stage for live partnership among trade unions as the union was to take the solidarity agenda as one of its primary goals. More interesting however, is the fact that TUCTA looks like a redundant union whose role is not clear for it seems to have failed to act as a collective force in bringing all trade unions together to champion the promotion and protection of workers' rights.

Trade unions in Tanzania have failed to even borrow some experience from other civil society organizations in the country. It is for instance argued that pro-human rights groups have to a great extent been successful in their demands because of their solidarity. A specific lesson is drawn from women rights movements such as Tanzania Media Women association (TAMWA), Tanzania Women Lawyers Association (TAWLA) and Tanzania Gender Networking Program (TGNP) which as a result of their collective pressure women status in the country has been progressively improving. Pointing out the role played by these organizations in democratization Mpangala (2006) argues that TAMWA, TAWLA and TGNP have had a leading role especially in advocating for gender equality. He argues that with the influence of these organizations there has been a significant improvement in women representation in decision making bodies such as the National Assembly. Quoting Killian, he points out that women representation in the parliament has been increasing over the years from $7.5 \%$ in 1965 to over $30 \%$ by 2006 . On the contrary solidarity and partnership among trade unions in the country is yet to be seen and there is no indication that trade union leaders are taking it seriously. 


\subsection{Unions' leadership failure}

From a management point of view, it is the role of a leader to show the mission and vision of the organization. As Ibreck (2009:9) emphasizes, leadership is a process of social influence in which one person is able to influence and enlist the aid and support of others in the accomplishment of a common task. Leaders carry out this process by applying leadership attributes such as their beliefs, values, ethics, character, knowledge and skills. Whether trade unions participate effectively in influencing the political system or not sometimes depend on the smartness of these leaders. However, the experience in Tanzania shows that trade unions have had weak leadership. It is only Tanzania Railway Workers Union (TRAWU) and teachers' trade unions (CWT) leaders who seem at least active in challenging government decisions and actions. The leaders of the two unions have been at least using various means such as boycotts, strikes and the media to influence the government.

For instance, CWT has been calling for strikes so as to exert more pressure to the government to pay teachers' outstanding claims. In various occasions TRAWU was involved in confrontations with the government as the union was at loggerheads with the management of Tanzania Railways Limited (TRL). While the two unions above have been trying to influence the government, TUCTA, which is an umbrella union, has since its establishment not been strong and capable of leading its member unions to effectively protect and defend the interests of their members. Notwithstanding a number of problems facing TUCTA such as inadequate financial resources and limited commitment of member unions, it is evident that the leadership of this umbrella union has not been effective. It is only in 2010 that the union has at least stood firm to challenge the government by calling for the $5^{\text {th }}$, May nationwide workers' strike. This strike was however called off following an embarrassing accusation and threats from the president of the united republic of Tanzania to TUCTA's leadership. Although it is difficult to measure the degree of one's commitment to the organization, it is obvious that trade unions leaders during the colonial period and immediately after independence were more committed towards defending workers' interests than it is for most of today's trade unions' leaders. For instance, in spite of government's move to weaken the trade union movement by appointing Tumbo ( who was the leader of TFL) as the High commissioner to London, he later resigned and came back to lead the trade union movement in Tanzania (Tandon 1979). What is always said to be the main problem to most of current trade union leaders is a "hangover" of single party control in which most of the leaders find it difficult to confront the state (challenging the state looks like a taboo). These leaders belong to a generation that witnessed trade unions being made to look like agents of the ruling political party (TANU and later CCM). This experience deprives trade unions of a leadership that can coordinate the struggle for the protection of workers' rights.

\subsection{Ideological and cultural conservatism}

Trade unions in Tanzania are politically dormant because they prefer a passive approach in encountering the state. There have always been no firm actions initiated and organized by trade unions that are meant to put pressure on decision makers. The tendency of trade unions to embrace a passive culture can be historically traced. Since 1961 when Tanzania got her independence, trade unions were strictly controlled by the state to the extent that their fate was subjected to the ruling party. These unions became passive observers that had no any recognizable role in post independence Tanzanian politics. Although this systemic control has lapsed, its legacy continues to negatively affect trade unions. These unions do not seem to have courage of actively confronting the government in an attempt to protect workers' rights. For instance, explaining the failure of trade unions to influence public policies, Gonza (2005:6), who is a trade unions' representative complains that there has been the marginalization of trade unions in major policy issues like the adoption of Structural Adjustment Programme (SAPs) in 1980s and their associated measures as trade unions were not consulted. His assertion sheds light on the role the trade unions have had in influencing government decisions.

Blaming the government for not consulting the trade unions indicates that trade unions are not actively struggling to defend the interests of their members. This is mainly due to the fact that an active trade union will always not just wait for consultation but will instead use whatever means available to influence decision making processes at any time so as to make sure that the interests of its members are protected. If trade unions were politically active one would have expected to see a more active response through various ways such as demonstrations, strikes and media campaign in trying to make sure that those policies represented their interests. However such kind of a response was not witnessed. This weakness better explains the continuing failure of workers' protests against various policies affecting their interests.

Limited trade unions' participation in democratization is also a result of relying too much on the ideology of economism while refraining from getting involved in politics. As Shivji (1983:17-19) argues, with the attainment of political independence, politics became the domain of the ruling party TANU in which trade unions were to be apolitical and concentrate only on purely economic matters. What still stands as a legacy of that dichotomy is that trade unions do not take political involvement as a mechanism that can be used to address the problems currently 
facing the workers. Their daily struggles have therefore tended to be against individual employers (investors) at the workplaces while giving little attention to the significance of the political role as suggested by Gompers (1987) and Przeworski (1989). It appears as if trade unions have been failing to identify the sources of the problems facing their members. For example, various confrontations between the workers and foreign investors have been continuously reported especially since the launching of privatization policy in which workers have been complaining against excessive powers granted to the investors. However issues like excessive discretionally powers of foreign investors need to be looked at from a wider perspective that includes the country's policy making processes. Attacking the investors without touching the root cause of the problem seems to have not been a solution to workers' problems.

\section{Conclusion and the way forward}

The above discussion has clearly indicated that trade unions in Tanzania still have a very frail role in democratization. This is mainly due to various factors such as a missing bond between trade unions and opposition parties which is attributed to the continuation of the ruling party's control of the political sphere, the fragility of the opposition, the failure of the opposition parties to introduce alternative policies, absence of a clear trade unions' political stance, opposition parties doubt about securing support from trade unions' members and the effect of lack of a collective match during the transition to multiparty politics. Trade unions' passivity has also been seen to be due to individualism and conflicts within trade unions. The paper has also clearly indicated that trade unions are politically weak because they still embrace the passive culture and are also excessively relying on the ideology of economism in which politics is not regarded as part of trade unionism. In addition, the leadership of trade unions, especially that of TUCTA has been weak and it has failed to create a sense of collective spirit among its member unions.

The above observation implies that the adoption of liberal politics in Tanzania has neither marked the end of an era in which trade unions were unable to effectively promote and protect workers' rights nor has it paved way for the beginning of a new era where trade unions are politically active. This observation is therefore an alarming signal to all trade unions' stakeholders that they have to examine current inefficiencies and propose discern measures to address them so as to ensure that they actively participate in politics.

\section{References}

Bagenda, P. (1994). The Ruling Party and the Transition to Multiparty System in Tanzania. In Mmuya, M (ed). The Functional Dimension of the Democratization Process: Tanzania and Kenya, with some experiences from former Eastern Europe. Dar es Salaam University Press, Dar es Salaam Tanzania

Baregu, M. (1993). The Economic Origins of Political Liberalization and Future Prospects. In Bagachwa, M.S.D \& Mbele, A.V.Y (eds). Economic Policy Under Multiparty System in Tanzania. Dar es Salaam University Press, Dar es Salaam, Tanzania.

Bavu, I (2006) Beyond Election Manifestos: Tanzania's 2005 Election. A paper presented at the $14^{\text {th }}$ state of politics conference in Tanzania. REDET

Chambua, S (2002). Democratic Participation in Tanzania: The Voices of Workers Representatives. Dar es Salaam University Press.

Friedland, W.H. (1969). Vuta Kamba. Hoover Institution Press, Stanford University, London.

Gershman, C., \& Allen, M. (2006). The Assault on Democracy Assistance. Journal of Democracy, Volume 17, Number 2,

Gibbon, P. (1995). Liberalised Development in Tanzania. Studies on Accumulation Processes and Local Institutions. Uppsala: Nordiska Afrikainstitutet., Sweden.

Gompers, S. (1987). Labour and the Common Welfare. In Werther W.B. Personnel Management and Human Resources. McGraw-Hill Book Company New York.

Gonza, J.M (2005). "Workers and Unemployment". A paper presented at the conference on the state of Politics in Tanzania held at the University of Dar es Salaam.

Havnevick, K. (1993). Tanzania. The Limits to Development From Above. Mkuki na Nyota Publishers, Dar es Salaam Tanzania.

Ibreck, J. (2009). Leadership as Key to Radical Socio-Economic and Religious Transformation for Tanzania. Reality: The Basis of Moral Leadership and Integral Human Development. Christian Professional of Tanzania (CPT)

Makulilo, A. (2007). Tanzania: A defacto one party state? (Unpublished masters dissertation). University of Dar es Salaam. 
Mallya, E (2006). Inter-Party Democracy. A paper presented at the $14^{\text {th }}$ state of politics conference in Tanzania. REDET

Martin, R. (1989). Trade Unionism: Purposes and Forms. Oxford: Clarendon Press.

Meena, R. (1997). The State and Civil Society in Tanzania: The State of Art. In REDET Project. Political Culture and Popular Participation. Dar es Salaam University Press, Dar es Salaam, Tanzania.

Mihyo, P.B. (1979). Industrial Relations in Tanzania. In Ukandi G. Damachi. Industrial Relations in Africa. Macmillan Press Ltd, London.

Moshi, H.P.B. (1993). The Commercialisation and Privatization of Public Enterprises in Tanzania: Successes, Problems and Prospects. In Bagachwa, M.S.D \& Mbelle, A.V.Y.(eds). Economic Policy Under A Multiparty System in Tanzania. Dar es Salaam University Press, Dar es Salaam, Tanzania.

Mpangala, G (2006). "Civil Society". A paper presented at the conference on the State of Politics in Tanzania held at the University of Dar es Salaam.

Mukandala, R.S.\& Bana, B. (2006). The search for independent organization; The Long Road to the TUCTA. In Kiondo, A.S and Nyang'oro J.E (eds). Civil Society and Democratic Development in Africa. Harare, Zimbabwe

O'Donnell, G., Schmitter P. \& Whitehead L. (eds.) (1986). Transition from Authoritarian Rule. Prospects for Democracy: Comparative Perspectives. vol. 3. Baltimore: Johns Hopkins University Press

Panitch, L. (1979). The Development of Corporatism in Liberal Democracies. Stanford University Press, London.

Perlman, S. (1928). A Theory of the Labour Movement. New York: The MacMillan

Przeworski, A. (1989). Democracy as a Contingent Outcome of Conflicts. In Elster, J. and R. Slagstad: Constitutionalism and Democracy. Cambridge: Cambridge University Press, 1989.

Rakner, L. (1992). Trade Unions in Processes of Democratization. A study of Party Labour relations in Zambia. Chr Michelsen Institute.

Schillinger, H.R. (2005). Trade Unions in Africa: Weak but feared. Friedrich-Ebert Stiftung

Shivji, I.G. (1983). Working Class Struggles and Organisation in Tanzania, 1939-1975. Mawazo Vol.5 No. 2.

Tandon, Y. (1979). In defence of Democracy. Inaugural Lecture Series No.14, University of Dar es Salaam.

Tanzania Union of Industrial and Commercial Workers (2000). The Union's Constitution.

Tordoff, W. (1967). Government and Politics in Tanzania. East African Publishing House, Nairobi, Kenya.

United Republic of Tanzania (URT). 2004. Employment and Labour Relations Act No.6

URT. (1998). Trade Unions Act No 10.

Webb, B., \& Webb. S. (1894). The History of Trade Unionism. London: Longmans and Green

Webster, E. 2007. Trade Unions and Political Parties in Africa: New Alliances, Strategies and Partnerships. Friedrich Ebert Stiftung

Notes

Note 1. Ibid

Note 2. Mihyo, op.cit

Note 3. Chambua, S (2002)

Note 4. Tanzania Railways Limited (TRL) was formed following an agreement between Rites Limited of India and Tanzanian government in which Rites was to take over the duties which were formerly performed by Tanzania Railways Corporation (TRC). Ever since there was a misunderstanding between TRL management and the employees over compensation issues and other work-related problems. However, the contract between the government and Rites India has recently been terminated thereby bringing TRL under full government control.

Note 5. Daily News, Tuesday, May $4^{\text {th }}, 2010$

Note 6. Ibid

Note 7. For more on union-party relationships see Edward Webster (2007)

Note 8. Ibid

Note 9. Mtanzania, March $5^{\text {th }}, 2010$ 